state of a town, and in that way sewered towns may still be exposed to the evils arising from "excrement-sodden soil" which the Medical Officer of the Privy Council has pronounced to be one of the main causes of cholera and fever.

Another point in which there is reason to believe existing sanitary arrangements are defective is the facility of communication between sawers and the dwellings from which they are intended to convey refuse. Some connection of the kind is indispensable for the use of water as a transporting vehicle for the refuse; but little attention has yet been paid to the fact that the very arrangement which facilitates the water-carriage of refuse also favours the regurgitation of foul gases from the sewers into streets and dwellings. The water traps and syphons commonly attached to the fonnections between houses and sewers are seldom or never sufficient to prevent the passage of gases; and in this way the inhabitants of sewered towns may be exposed to the unwholesome influence of a constant pollution of the atmosphere as pernicious in its action as the use of water polluted with drainage from cesspools, or living over an excrement-sodden soil, has long been recognised to be.

These are some of the chief points which the limits of the present article will admit of being noticed as being comprised in the inquiry to be carried out by the British Association Committee.

BENJAMIN H. PAUL

\section{SCIENCE FOR CHILDREN}

THE schoolmasters of the present day may be divided 1 into two categories: those who teach, and those who hear lessons; the latter class, unfortunately for the next generation, being by far the more numerous. The mischief done to the community generally by the shortcomings of inefficient teachers is too well known to every one who has pierced below the surface of the great question of middle-class education. The difficulties, however, that beset a science teacher in his endeavours to force scientific truths into the univilling and unprepared minds of boys, who have been subjected to the sway of these same lesson-hearers, can only be realised by those who have gone through the task. The case of a senior science class, which has been under my charge for some months past, will illustrate my meaning most fully. It consists of about a dozen boys, whose ages range between fourteen and seventeen years, and they receive twice a week an hour's instruction on chemistry and physics. The class may be divided into two distinct portions by a perfectly sharp line. Four of the boys have had the advantage of six or seven years' training under the principal of the school, who is not only a ripe scholar, but also an efficient teacher-a very rare collocation in these days. The rest have simply learnt lessons all their lives. The four boys who have been taught are as mentally distinct from the others, as if they. were different species of the same genus. The first four are bright, attentive, wide-awake-I know of no other term to express exactly what I mean-logical, and ciear-headed ; they can fairly follow a chain of scientific reasoning, and reproduce it afterwards link by link; they have a certain power of induction and deduction, although of course, being new to science, this power is necessarily only just awakened; they can connect and correlate facts and ideas, they can enumerate a series of phenomena in logical sequence; in a word, although their industry and application are far from colossal, the task of teaching them the truths of natural science is a comparatively easy one. The other boys, as I have said before, almost form a distinct mental species. They cannot understand the possibility of learning anything without the aid of a book, and the idea of fincling out anything for themselves has never entered their heads. Still they are far from stupid boys, being all possessed of good average brains; yet their faculties have not merely been allowed to remain undeveloped, but they have been utterly entangled, stunted, and stultified by what Dr. Frankland would call their "previous school contamination." These boys, it must be understood, are the sons of parents belonging to the upper stratum of the middle class, and have mostly been to schools conducted by university men. with honourable initials appended to their names-men, in fact, who are scholars but emphatically no teachers. Their great fault is a total want of mental method, without which the greatest brain is as nought. They are at home in Virgil and Horace, some of them are fair Greek scholars; they have "been through" Euclid, and can work moderately difficult algebraical problems in a certain mechanical fashion; they are well acquainted with the leading facts of English history, and know the exact position and population of Adrianople; but as far as real mental power goes, any poor boy, who has been in a National school for three years, would beat them hollow.

These facts surely point out the absolute necessity of beginning scientific training at a very early age; and I fancy this necessity has not been sufficiently dwelt upon in the numberless essays, letters, lectures, and evidence on the subject of scientific education with which we have been deluged during the past decade. There seems to have been a notion abroad, that scientific teaching should not be begun before the age of 12 or 14 ; but why, I would ask, should boys' minds be allowed to remain fallow during all these years? The minds of boys of 7 and 8 should surely be as carefully developed as those of their seniors, and there is certainly no means of pure mental culture so successful as scientific teaching. A boy of this age should not be taught science so much for the sake of acquiring a certain number of facts, as of developing his powers of observation and reasoning, and giving a proper tone to his mental faculties. A boy of 8 or 9 takes a morning canter of three or four miles on his pony, not for the purpose of getting over some 7,000 yards of ground, but to strengthen his muscles and improve his carriage: his science lesson should be an intellectual canter, taken with the view to strengthening and improving his mental muscles and carriage.

In National and British Schools, and in some few middle-class schools conducted on rational principles, this great want is supplied by what are known as "Object Lessons." A natural object, such as a piece of lead or sugar, is placed before the class, and its physical properties are described by the pupils with the aid of questions from the teacher. Its origin and manufacture are also given in the case of the older children, and the whole is noted down on the black-board in as condensed a manner as possible; the lesson being reproduced in a miniature form either vivat voce or in writing. These lessons are 
most excellent in their way ; but as generally taught, they are too desultory and unsystematic to effect fully their intended purpose. The principal manuals on the subject show a want of arrangement and system, that greatly detracts from their value. One day the children are supposed to learn a lesson on a piece of iron : the next on a flower, the third on a shell, and so on. Too much stress is laid upon cultivating the powers of observation, and too little on connecting the facts observed, and drawing conclusions from them. The lessons, too, are very frequently unconnected with each other, and the facts taught lean almost too much towards the practical and economic side of knowledge, and too little to that of systematic science. Great scientific ignorance is displayed in many cases: for instance, one book informs us that plumbago is an ore of iron; that iron is generally found as an oxide in combination with sulphuric and carbonic acid; that fluor spar is composed of fluoric acid and lime; and that lime unites with various proportions of carbonic acid. These mistakes are the result of imperfect scientific knowledge, and may be passed over for the sake of the valuable instruction given to teachers, which cannot fail to produce most excellent results, if applied to systematic scientific teaching.

It may be urged that children of 8 or 9 are too young for systematic science teaching, but facts prove the contrary. An ordinarily intelligent boy or girl of this age is perfectly capabl z of understanding the broad differences between the animal, vegetable, and mineral kingdoms; that there are more gases than one in the world; that some of them are colourless, while others are brown or creen; that some burn and others do not; that some plants grow from the inside, while others grow from the outside; that some animals have jointed backbones, that others have their bones outside their bodies, while others have none at all. Facts such as these are perfectly comprehensible to children even younger than those I have named. J) uring the first two years of a child's school life, after he has learned to read and write, he should be carried through the whole range of physical science in a systematic manner. The fundamental truths of chemistry and physics should be first taught him: all theoretical considerations being left aside. As few definitions as possible should be given, the whole task of the teacher at the commencement being to cultivate the child's powers of obsarvation to the utmost. Gradually the powers of induction and deduction may be developed, facts and phenomena should be compared, and conclusions drawn from them. Order in thought and description should be specially insisted upon, and occasional retracings of the ground already gone over should take place. The objects of this preliminary science teaching should be twofold: first and foremost, to train the mind and form the judgment; and secondly, to give the child a general idea of the object and scope of the natural sciences. At the age mentioned, the faculties are all fresh, and in full process of development; and such is the desire to exercise them in intelligent children, that their thoughts often run wild. There is nothing a child likes so much as investigation, or "finding out all about things," as he himself wonld phrase it. The boy in the nursery rhyme who cut the bellow's open to see where the wind came from, is a type of his class. Unfortunately at the present time, scientific teachers for children are extremcly rare, but let the want once arise, and the demand will soon be met. We have plenty of scientific teachers and lecturers for boys and men, but the child has hitherto been left out of consideration. Teachers, in the true sense of the word, are every day on the increase, and even the oldfashioned schoolmasters are beginning to see very plainly that they must alter their system of instruction, and yield to the pressure of the times. But it is not only upon these that I would urge the necessity of beginning science teaching at the earliest possible period, but also upon those who have already adopted science as part of the ordinary school curriculum for the older boys.

\section{CHARLES W. QUIN}

\section{THE GOLD FIELDS OF TICTORIA}

The Gold Fields and Mineral Districts of Victoria. J3y R. B. Smyth. (Melbourne: J. Ferres. London: Trübner and Co.)

\section{I}

TWENTY short years ago, the territory of Southern Australia comprised within the colony of Victoria offered comparatively little attraction to the emigrant. Its population had increased but slowly during the half century which had passed away since the discovery of Port Phillip Bay. Graziers, shepherds, and farmers were its chief occupants, and by them the value of its soil was estimated very much according to the number of cattle or of sheep which each acre could maintain. But to-day. everything is changed. The land is dotted with hamlets, villages, and towns, and is intersected with roads and railways. The population has increased from 77,000 in I 85 I, to 660,000 in 1867 . In the former year only 57,000 acres were under cultivation, in the latter the area had risen to 631,000 . This growth in the population has been accompanied by a corresponding increase in the value of the imports and exports, which are now ten times what they were; while the value of rateable property in town and country districts is estimated at about $£ 42,000,000$.

This marveliously rapid risce of the colony is mainly to be ascribed to the discovery of gold there in $185 \mathrm{I}$. Never had the prospects of the colony been gloomier than just before that discovery was made. The able-bodied part of the population was moving off to the gold-fields of New South Wales, glowing accounts of which appeared from week to week in the newspapers. Every kind of property was sinking in value. At last, after small finds of gold had been reported from different parts of Victoria, a public meeting of the citizens of Melbourne was convened, for the purpose of raising funds towards offering a reward to any one who should discover a workable gold mine within twenty miles of that town. The attention of the colonists was now thoroughly roused, and in the course of a few weeks reports came from many of the surrounding districts that gold existed in large quantities. From that time the tide of emigration from the colony was arrested, and the population began to increase with that wonderful rapidity just alluded to.

From the very beginning of the mining operations they were regulated and inspected by the Colonial Government. A mining department was instituted, with a responsible minister at its head. Mining registrars and surveyors, wardens of mining districts, and other officials were appointed with the view of aiding and regulating the labours 